Dear Author,

Please, note that changes made to the HTML content will be added to the article before publication, but are not reflected in this PDF.

Note also that this file should not be used for submitting corrections. 
Full length article

\section{From mice to mind: Strategies and progress in translating neuroregeneration}

\section{A R T I C L E I N F O}

\section{Article history:}

Received 5 January 2015

Received in revised form

18 February 2015

Accepted 12 March 2015

\begin{abstract}
A B S T R A C T
Decisions about what experimental therapies are advanced to clinical trials are based almost exclusively on findings in preclinical animal studies. Over the past 30 years, animal models have forecast the success of hundreds of neuroprotective pharmacological therapies for stroke, Alzheimer's disease, spinal cord injury, traumatic brain injury and amyotrophic lateral sclerosis. Yet almost without exception, all have failed. Rapid advances in stem cell technologies have raised new hopes that these neurological diseases may one day be treatable. Still, how can neuroregenerative therapies be translated into clinical realities if available animal models are such poor surrogates of human disease? To address this question we discuss human and rodent neurogenesis, evaluate mechanisms of action for cellular therapies and describe progress in translating neuroregeneration to date. We conclude that not only are appropriate animal models critical to the development of safe and effective therapies, but that the multiple mechanisms of stem cell-mediated therapies may be particularly well suited to the mechanistically diverse nature of central nervous system diseases in mice and man.
\end{abstract}

(c) 2015 Published by Elsevier B.V.

\section{Introduction}

\subsection{The case for neuroregeneration}

Table. 1 Modern medicine has made disproportionately modest progress in the management of neurological diseases. In other fields, from open-heart surgery and organ transplantation to antibiotics, vaccinations and improved management of multiple cancers, science and medicine have much to be proud of. However, the cumulative burden from neurological diseases has experienced little relief. Traumatic brain injury is still the leading cause of morbidity and mortality in young adults. Patients paralyzed by spinal cord injury during the last century have been witness to the description of human embryonic stem cells (ESCs), the sequencing of the human genome and the development of induced pluripotent stem cells (iPS)-an accomplishment deemed so important that that it earned a Nobel Prize only 6 years after its discovery. Yet, despite these accomplishments, paralyzed patients can still only dream of one day walking again. Meanwhile, Alzheimer's disease has become the fastest growing cause of death in our aging population.

\footnotetext{
* Corresponding author.

E-mail address: tcburns@stanford.edu (T.C. Burns).
}

\subsection{Paralyzed, demented scientists: can their mice save them?}

The goal of restoring function to patients with neurodegenerative disease, spinal cord injury, stroke, and traumatic brain injury increasingly occupies the careers of thousands of scientists. Yet for none of these ailments is a probable cure close to being found. This is not for lack of productivity. Tens of thousands of papers have been written, many of which have described significant neurological recovery of rodent models. In contrast to human patients, previously paralyzed rats now DO walk again, Alzheimer's mice can relearn their way out of mazes, and hemi-Parkinsonian rats enjoy symmetric motor function. Based on compelling preclinical data, numerous clinical trials have been launched at momentous expense, testing the faith, hope and trust of thousands of patients. Yet, virtually without exception, all have failed. Scientists nevertheless keep breeding their mice and new cures for these vermin continue to grace the pages of high-ranking scientific journals. Are scientists dementedly performing mouse experiments again and again, having so quickly forgotten their dismal predictive value? Has the ability to recurrently cure their fury friends in novel ways paralyzed scientists' abilities to focus on the human problem?

\subsection{Why stem cells?}

Against this bleak backdrop of failed attempts to halt degeneration, repair injury, or induce plasticity using standard pharmacotherapies, the concept of harnessing the potential of stem cells-nature's own 
Table 1

Overview of major neuroregenerative strategies evaluated in animal models.

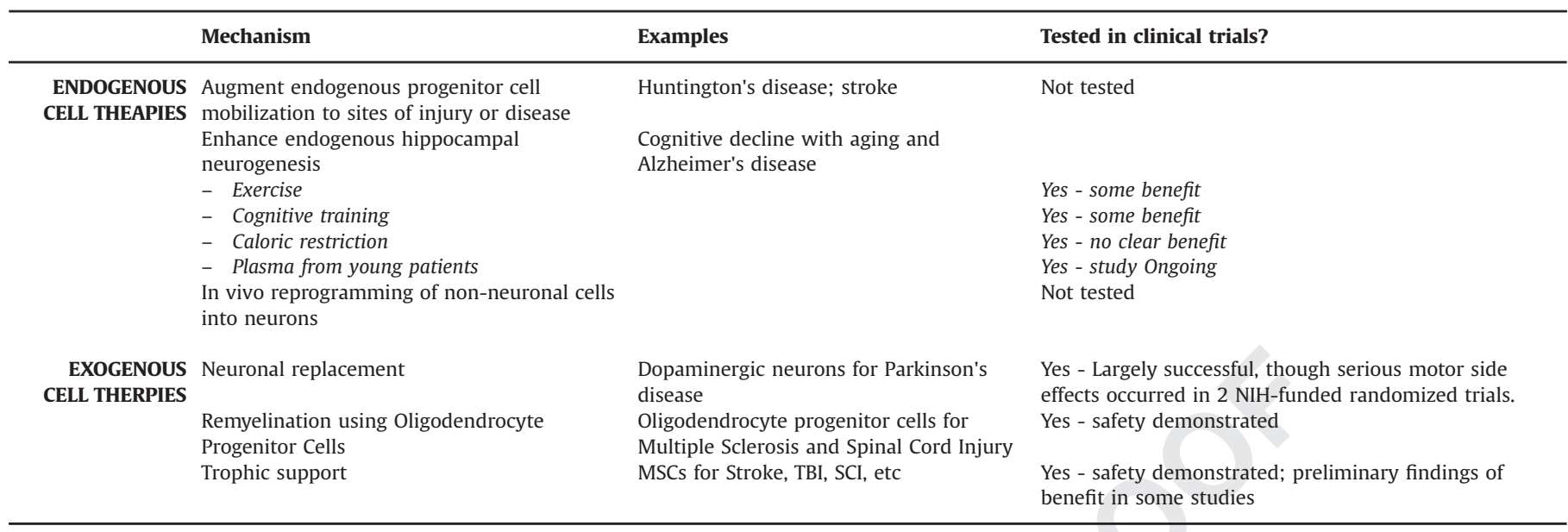

agents of regeneration and self-renewal-is appealing. One can understand the sense of optimistic anticipation in paralyzed patients who with iPS cell technology can now see their very own skin cells reprogrammed into stem cells and differentiated into spinal cordtype cells in a dish. More than just factories for making neurons and glia, however, stem cells are increasingly recognized as first responders to injury in their own right, endowed with capacity to promote angiogenesis, modulate inflammation, and secrete neurotrophic compounds. Even stem cells from within the injured spinal cord itself have been shown to play an active role in mitigating collateral injury to surrounding neurons (Sabelstrom et al., 2013).

Despite optimism for the potential stem cells hold for neurological diseases, very real challenges remain to translate stem cellbased regenerative strategies into clinical cures. Virtually all translational efforts depend upon evidence obtained from animal models. How that evidence is obtained and how it is interpreted can make or break its relevance.

\section{Endogenous neurogenesis}

\subsection{Hippocampal neurogenesis}

In his 1928 essay "Degeneration and regeneration of the nervous system," neuroscientist Ramón y Cajal famously wrote, "In adult centers the nerve paths are something fixed, ended, immutable. Everything may die, nothing may be regenerated. It is for the science of the future to change, if possible, this harsh decree."(Ramon y Cajal, 1928) This view stood unchallenged until 1965 when Altman and Das provided autoradiographic and histological evidence of neurogenesis in the adult rat hippocampus (Altman and Das, 1965a,1965b). Although these findings were largely ignored for the next 2 decades, Goldman and Nottebohm (1983), reported production of new neurons in a vocal control nucleus of adult female canaries that were associated with the seasonal acquisition of song. In 1998, the Gage lab provided evidence for neurogenesis in the adult human hippocampus (Eriksson et al., 1998). To date, hippocampal neurogenesis has been evaluated in at least 71 mammalian species and found to be present in almost all, with the exception only of Cetaceans (whales, dolphins and porpoises; (Patzke et al., 2013). While the function of hippocampal neurogenesis remains under active investigation, current evidence supports a role in memory and spatial navigation. Newly born neurons provide a cellular substrate for plasticity that manifests as they integrate into circuitry several weeks after birth. Multiple magnetic resonance (MR) imaging studies have reported correlations between human hippocampal size and memory-dependent activities, with increased size in taxi drivers (Maguire et al., 2000) and medical students studying for exams (Draganski et al., 2006). Physical exercise is positively correlated with neurogenesis, while neurogenesis is decreased in association with stress, depression, neurodegeneration, and agerelated cognitive decline. In rodents, hippocampal neurogenesis declines precipitously during young adult life. By contrast, hippocampal neurogenesis was recently shown by carbon-14 dating to be substantial in adult humans, supporting the idea of an active role in cognition (Spalding et al., 2013). The finding that hippocampal neurogenesis persists into adult life supports the notion that therapies to reverse age-dependent hippocampal atrophy could improve cognition (Jessberger and Gage, 2014). Indeed, interventions known to improve hippocampal neurogenesis including exercise and cognitively demanding tasks enhance cognitive performance in aged humans (Bherer et al., 2013). In a recent exciting experiment, blood plasma from young mice or humans improved hippocampal neurogenesis, cognitive performance and several other physiological parameters of youthfulness in aged mice, offering hope that therapies to promote "rejuvenation" may soon be within reach (Villeda et al., 2014). Although the therapeutic mechanisms of young blood remain poorly understood, a clinical trial for patients with mild-to-moderate Alzheimer's disease is underway (NCT02256306; www.clinicaltrials.gov).

\subsection{Subventricular zone neurogenesis}

During development, much of the forebrain brain develops from a peri-ventricular germinal region, which persists in adults as the second major site of neurogenesis-the subventricular zone (SVZ). In rodents and non-human primates (Kornack and Rakic 2001 ) SVZ-derived neuroblasts migrate through the rostral migratory stream to generate new olfactory bulb (OB) neurons, which play a critical role in olfactory discrimination and memory (Alonso et al., 2012; Alonso et al., 2006; Imayoshi et al., 2008; Mouret et al., 2009). Nevertheless, the contribution of the human SVZ to olfactory neurogenesis has proven controversial (Curtis et al., 2007; Sanai et al., 2004). Most recently, a comprehensive study using carbon-14 dating, thymidine analog incorporation and immunohistochemical analysis found no evidence for human olfactory bulb neurogenesis. Unexpectedly, however, substantial numbers of newly born neurons were found in adult human striatum adjacent to the SVZ (Ernst et al., 2014). This represents a substantial departure from rodents where no evidence exists for striatal neurogenesis in healthy adults. Many questions remain 
regarding the regulation and functional importance of what now appears to be the second major site of neurogenesis in adult humans, though importantly, reduced neurogenesis was found in patients with Huntington's disease (Ernst et al., 2014).

Of particular relevance to attempts at neuroregeneration, injury stimuli such as stroke have been shown to divert rodent neuroblasts from their usual course along the RMS to the brain parenchyma towards the peri-infarct region. Although very few such cells survive or mature to become functional neurons, diversion of these newly generated cells to the infarct region continues for up to a year in rodents, and genetic ablation of such newly generated cells worsens outcomes (Jin et al. 2010; Sun et al. 2013; Sun et al. 2012; Wang et al. 2012.) Using carbon-14 dating, no new neurons were found in human cortex after stroke though the situation after human striatal stroke remains to be evaluated (Huttner et al., 2014). Interestingly, although no striatal neurogenesis occurs in healthy rodents, intraventricular delivery of adenoassociated viruses encoding brain-derived neurotrophic factor (BDNF) and noggin resulted in sustained mobilization of SVZ neural stem cells (NSCs) to the striatum of Huntington's mice. These neurons differentiated into functional medium spiny neurons of the type lost in Huntington's and treated mice showed improved motor function and prolonged survival (Benraiss et al., 2013). While much attention has focused on neuronal progeny of the SVZ, this region can also give rise to glia as well as progenitors that migrate to the site of injury but remain undifferentiated. The functional importance of such non-neuronal progeny remains to be fully evaluated (de Chevigny et al., 2008; Kojima et al., 2010; Menn et al., 2006).

\subsection{Alternate central nervous system progenitor pools}

Finally, other progenitor populations exist in the human brain outside of neurogenic regions. Oligodendrocyte progenitor cells exist throughout the brain and respond to demyelinating injuries (Franklin and Ffrench-Constant, 2008; Hartley et al., 2014). Although cell turnover in the normal adult human white matter is low, myelination appears highly dynamic and may contribute to adult central nervous system (CNS) plasticity (Yeung et al., 2014). Moreover, recent evidence in rodents suggests new oligodendrocytes may be born in response to neuronal activity and enhance pathway function (Gibson et al., 2014). Certain populations of astrocytes appear to be developmentally closely related to NSCs, and inhibition of notch signaling in mouse astrocytes can trigger in situ striatal neurogenesis (Magnusson et al., 2014). Moreover, new technologies of epigenetic reprogramming have opened the door to in vivo reprogramming of one cell type to another. Overexpression of key transcription factors such as Neurogenein2, Mash1 or Sox2 can convert pericytes, astroglia or oligodendrocyte progenitor cells into functional neurons in situ (Heinrich et al., 2014; Heinrich et al., 2010; Karow et al., 2012). Such exciting technologies offer unprecedented potential to fundamentally reconfigure the structure and function of diseased brain regions. Of course, before clinical trials can be considered for any such strategies, animal models will again find themselves indispensable for rigorous evaluations of long-term safety.

\section{Exogenous stem cells}

Long before endogenous neurogenesis was widely recognized, loss of specific neurons in certain diseases, such as midbrain dopaminergic neurons in Parkinson's disease, prompted hopes that the replacement of these neurons could prove therapeutic.

In the 1970s, Anders Bjorklund's lab in Lund, Sweden began investigating the potential of transplanted fetal tissue to integrate into the adult CNS (Bjorklund et al., 1976). In contrast to Cajal's predictions, Bjorklund found that the CNS could accept the addition of new cells to generate functional connections. This and subsequent work ultimately paved the way for clinical trials of fetal dopamine cells for Parkinson's disease. Given the limited supply of fetal brain tissue, the discovery of neural stem cells (Reynolds et al., 1992; Reynolds and Weiss, 1992) prompted hopes of a potentially unlimited supply of new cells for transplantation. In the late 1990s to early 2000s evidence from several labs suggested that developmental boundaries restricting cells to specific lineages could be overcome, potentially freeing even bone-marrow-derived stem cells to generate neuronal cells. Although some of these reports of "transdifferentiation" proved to be due to technical artifacts (Burns et al., 2006; Wurmser and Gage, 2002), preclinical studies with bone-marrow-derived cells, including mesenchymal stem cells (MSCs) nevertheless demonstrated functional benefits in rodent models of CNS disease (Burns and Steinberg, 2011; Burns et al., 2009); (Vu et al., 2014), suggesting the potential for functional benefits even in the absence of any new neurons.

\subsection{Multifunctional stem cells}

Two primary strategies of cellular therapy have emerged. "Cell replacement" strategies seek to replace the neuronal cell types lost through disease, with Parkinson's disease remaining the prototype. "Trophic" cell therapies, by contrast seek to restore function via indirect mechanisms, many of which remain ill-defined, but include modulating inflammation, promoting angiogenesis, augmenting endogenous neurogenesis, and secreting factors that support the survival, function and plasticity of remaining host neurons. Certain stem cell populations also migrate avidly toward regions of injury or neoplasia, thus helping to focus their activities at the site(s) of greatest need, and provide opportunities for focal delivery of therapeutic molecules (Lee et al., 2013; Song et al., 2010). Despite remaining mechanistic questions, the apparent multiplicity of stem cell actions, which contrasts with often highly targeted drug therapies, may prove to be a critical feature of cellbased therapies (Fig. 1). The complexity of CNS damage or degeneration, with its associated inflammation, oxidative stress, and impairment of mitochondrial, proteasomal and lysosomal function, may require a multimodal "all of the above" therapeutic approach, to which the numerous actions of stem cells may be particularly well suited.

Interestingly, such an "all of the above" approach may in fact be employed as part of the brain's natural response to neurodegeneration. We recently performed a transcriptional meta-analysis of neurodegenerative diseases, and identified a core module of neurodegeneration-associated changes conserved across amyotrophic lateral sclerosis (ALS), Huntington's disease (HD), Parkinson's disease (PD) and Alzheimer's disease (AD). Strikingly, network analysis revealed that SOD1, Huntingtin, Parkin and APP -each almost pathognomonic for changes associated with ALS, $\mathrm{HD}, \mathrm{PD}$ and $\mathrm{AD}$, respectively-were in fact all implicated in regulation of the observed transcriptional response across neurodegenerative diseases ( $\mathrm{Li}$ et al., 2014). One of the challenges in the field is to distinguish disease etiologies from beneficial responses. A recent critique of translational approaches to Alzheimer's disease suggested that strategies aiming to rid transgenic Alzheimer's mice of their APP-associated amyloid-beta plaques might be analogous to attempting to prevent deployment of airbags as a strategy to prevent motor vehicle accidents (Krstic and Knuesel, 2013). While deployed airbags are found in the majority of accidents; while accidental deployment has been shown to cause accidents in rare cases; and while experimental deployment of airbags would predictably lead to more accidents, strategies to 


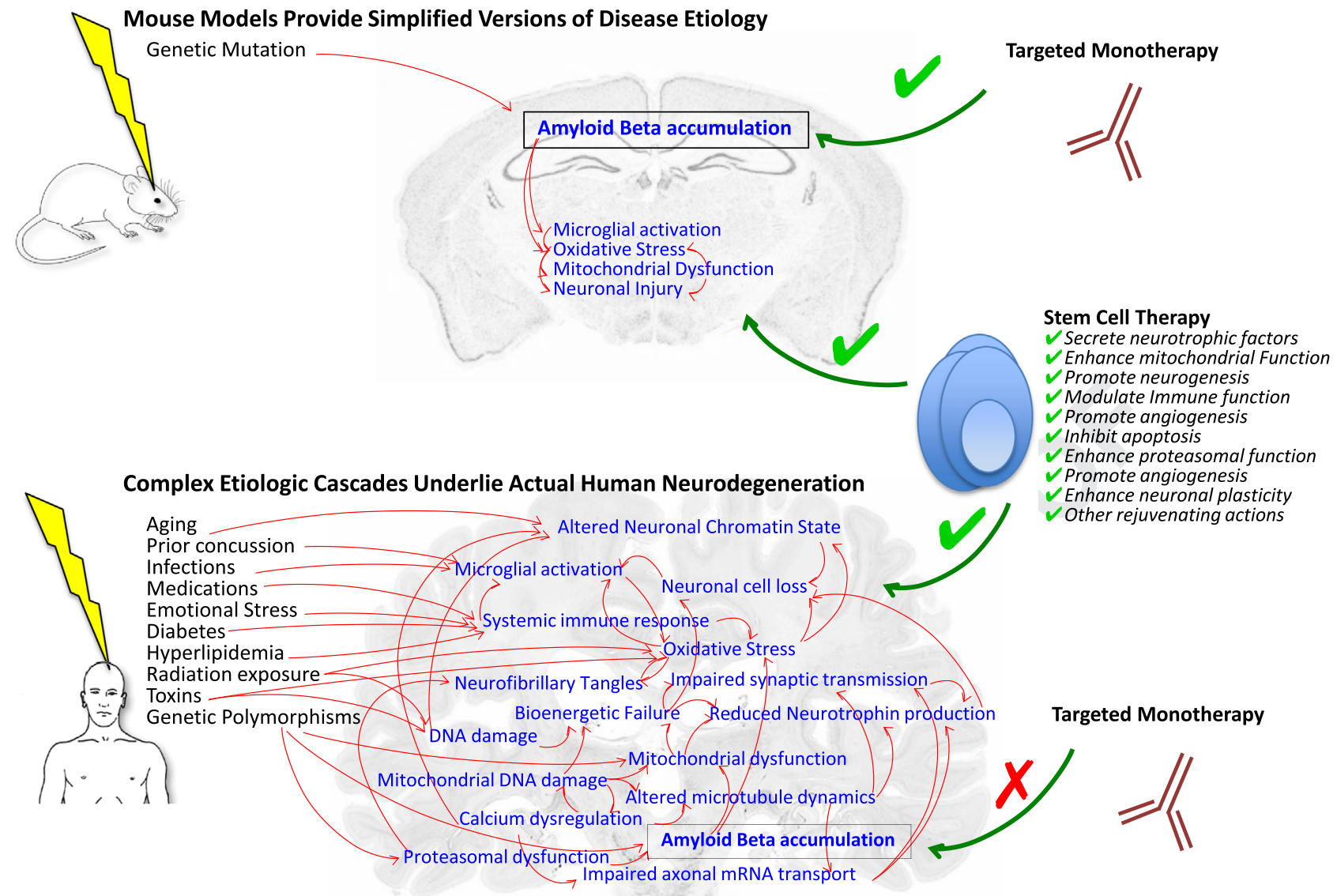

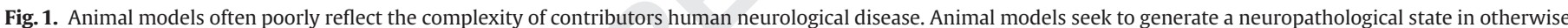

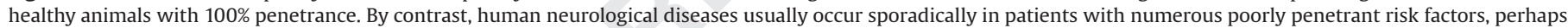

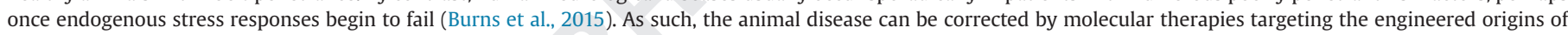

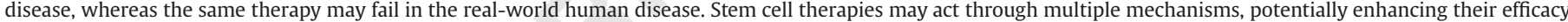

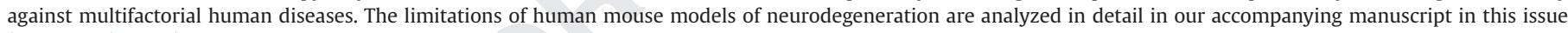
(Burns et al., 2015).

prevent airbag deployment are unlikely to decrease the number of motor vehicle accidents and may in fact worsen outcomes. Similarly, while amyloid plaques are found in most cases of Alzheimer's disease; while amyloid plaque formation may be the root cause of memory impairment in a small subset of familial Alzheimer's patients; and while experimental overexpression of an amyloid precursor protein can cause memory impairment in mice, clinical strategies to reduce amyloid have failed in clinical trials (Doody et al., 2014; Panza et al., 2014; Salloway et al., 2014).

By analogy, the "ideal" stem cell-based therapy would not only prevent accidental airbag deployment, but also improve road traction, enhance vehicle visibility, prevent speeding, promote driver alertness and inhibit driver intoxication and driver distraction. In this way, by acting through multiple mechanisms of action, stem cell therapies may ideally circumvent the problems of heterogeneous contributors to human neurological disease and imperfect animal models, by activating a spectrum of defenses to promote resilience against disease and injury. Indeed, we propose that much of the promise of stem cell therapies may be attributable to their multiple modes of action. In contrast to highly targeted pharmacological therapies that may be tailored to precisely correct the root cause of pathology in a given animal model and subsequently fail in the real world of human trials, optimized cell therapies may have the capability to positively impact a variety of animal models and succeed when faced with the more heterogeneous and complex pathologies of sporadic human neurodegenerative diseases (Fig. 1).
Even if true, this does not excuse scientists from more carefully studying both actual human disease to better define the true human mechanisms of CNS degeneration and the mechanisms underlying stem cell function. Such knowledge could undoubtedly be used to further improve future neuroregenerative therapies.

\subsection{Optimizing efficacy}

The poor predictive performance of preclinical animal models of CNS disease has prompted some to recommend a complete shift away from animal studies (Cavanaugh et al., 2014). Indeed, the transcriptome of neurodegenerative disease animal models often poorly captures key features of true human neurodegeneration (Burns et al., 2015) (see accompanying manuscript in this issue). Nevertheless, while we advocate caution extrapolating mechanistic conclusions from animal models to humans, it is conceivable that the first steps toward translation for cell therapies may depend less on animal models being perfect replicates of human disease, than upon their availability as intact biological systems within which to evaluate stem cell delivery, survival, proliferation, and migration. Full advantage of preclinical animal models must also be made to optimize therapeutic effects and safety of engrafted cells. Variables such as hypoxic or other forms of preconditioning may promote cellular trophic activities (Yu et al., 2013); side by side evaluation of optimal sources, ages and preparations of cells, should all be performed in animal models prior to clinical trials. Conceivably, successful performance across a 
variety of imperfectly rendered disease models may provide better predictive value than individual performance in even the most "relevant" animal model.

In order for cell therapies and trial protocols to improve in the future, thoughtful efforts must be made to maximize the data yield from current patients. CNS tissue must be harvested and banked from trial participants who succumb to their disease; serum should be harvested from participants and complement imaging studies. Although currently, we may not yet even know the right questions to ask, banking these samples for future analysis, possibly when new techniques emerge may prove critical. Perhaps future evaluation of cell-free RNA (Martinez et al., 2014) from banked serum will provide a signature of interactions between grafted cells and the host innate immune system that will explain why some patients showed a more dramatic improvement than others reveal how future cells may be modified to augment their impact. Currently, cells used in clinical trials lack identifying transgenic markers, confounding their identification in pathologic analyses of post-mortem tissue. This largely regulatory hurdle must be overcome to allow surviving grafted cells to be identified and analyzed. In vivo imaging strategies are also in their relative infancy; though superparamagetic iron oxide (SPIO) particles have been used clinically to label CNS transplanted cells for detection by MRI (Zhu et al., 2006), though it is difficult to exclude misleading signal from phagocytic cells if engrafted cells die after transplantation (Li et al., 2008b). Future use of appropriately engineered genetic constructs may permit unambigiuous in vivo identification of grafted cells by MRI or PET. Thus, while animal models are critical in the early stages of translation, a generous cohort of scientists must divert their gaze from mice, to the patients who received their mouse-endorsed therapies. Only in this way will the necessary data be gathered to optimize experimental human neuroregenerative therapies in the future.

\subsection{Primum non nocere}

Among several safety-related issue surrounding cell transplantation, the greatest concern surrounds tumor formation, which has been reported in humans receiving stem cell grafts outside of well-controlled clinical trials (Amariglio et al., 2009; Dlouhy et al., 2014). Tumors formation may occur for at least 3 reasons. First, in vitro culture may lead to accumulation of tumor-promoting genetic abnormalities (Jeong et al., 2011; Tolar et al., 2007). This risk is minimized by optimizing culture conditions to reduce stress, monitoring for changes in rate of cell proliferation, and routine evaluation of karyotype. However, even karyotypically "normal" cells may accumulate numerous smaller "occult" genetic abnormalities, the significance of which remains uncertain. As such, efforts should be made to minimize duration of culture for cells destined for clinical trials, whilst monitoring for genetic changes with high-resolution methods (Peterson and Loring, 2014). Second, the pluripotent nature of ESCs and iPSCs permits teratoma formation if any undifferentiated cells contaminate the graft. Great efforts have been invested in culture, sorting and screening strategies to ensure "pure" populations ESC-derived cells safe for clinical use (Lukovic et al., 2014; Polanco et al., 2013). Third, certain in vitro culture conditions have recently been found to enable spontaneous de-differentiation of bone marrowderived cells into hypoblast cells that can generate embryonic yolk sac tumors, even though cells may be derived from bone marrow and have normal Karyotype (Leten et al., 2014; Lo Nigro et al., 2012). As such, even cell types presumed to be "safe" based on their adult origin, lack of genetic manipulation and normal karyotype, must be rigorously evaluated for markers of dedifferentiation such as Oct4. Moreover, in some cases, tumor formation may be context dependent. Although no tumors were found with system or intramuscular cell delivery (Aranguren et al., 2008; Serafini et al., 2007), the same cells generated embryonic yolk sac tumors in nude mice (Leten et al., 2014; Lo Nigro et al., 2012) and after intracranial delivery. As such, there remains no substitute for rigorous long-term safety studies in animals, to evaluate the behavior of cells delivered at or above the passage number and density planned for clinical trials. Animal models are also critical for developing strategies, such as suicide constructs, that may augment the safety of cellular therapies in the future (Leten et al., 2014).

\section{From mouse to man: translation in progress}

In this section, we highlight translational steps taken to date for cell-based treatments of Parkinson's disease, stroke, spinal cord injury, ALS and Alzheimer's disease. While the reader is referred to more comprehensive reviews as appropriate for each disease, these sections illustrate challenges encountered and progress made in translating neuroregenerative therapies from animals to humans.

\subsection{Parkinson's disease-the Derailed prototype for CNS cell replacement}

Parkinson's disease has widely been viewed as the "ideal" neurodegenerative disease for cell replacement therapy, owing to the relatively select loss of a specific neuronal subtype- midbrain dopaminergic neurons (Bjorklund, 1992).

Animal models for cell transplantation studies have generally involved rodents treated with neurotoxins such as 6-OHDA or MPTP, to which midbrain dopaminergic neurons are selectively susceptible (Dauer and Przedborski, 2003). Such models are limited in that they fail to replicate the typically insidious onset of human neurodegeneration. Nevertheless, models of unilateral disease, such as following stereotactic injection of 6-OHDA, have enabled quantification of amphetamine- or apomorphine-induced rotational behavior, which may be reversed upon restoration of dopaminergic innervation to the striatum by fetal or stem-cellderived grafts (Kim et al., 2002).

Years of careful animal experimentation preceded the onset of clinical trials of fetal cell transplantation in the 1980s (Barker et al., 2013). Numerous open-label trials generally yielded favorable outcomes, with patients in many cases discontinuing their use of dopamine medications and experiencing improved motor function. A meta-analysis of 11 clinical studies including 95 patients suggested significant improvement after cell transplantation, with increased 18 F-fluorodopa uptake, decreased used of L-dopa, improved response to anti-Parkinsonian medications and a $36.6 \%$ overall functional improvement, as measured by Motor (off) United Parkinson's disease rating scale (UPDRS). Improved functional recovery correlated positively with younger age $(<60 \mathrm{yo})$, maintained immunosuppression, bilateral grafts, and post-transplantation viability of cells as measured by $18 \mathrm{~F}$-fluorodopa (Polgar et al., 2003).

In 2001 and 2003, two well publicized NIH-funded randomized double-blind placebo-controlled trials failed to meet their primary endpoints, and some patients unexpectedly developed severe dyskinesias (Freed et al., 2001; Olanow et al., 2003). Cell therapy for Parkinson's rapidly went from being the poster child of cell based therapies for neuroregeneration, to being labeled a failure. A moratorium on cell transplantation trials for Parkinson's was advised in 2003 while the field sought to understand where things went wrong (Robinson, 2003).

Issues investigated included immunosuppression and tissue preparation protocols, as well as graft composition and distribution. 
Among the differences in protocol between these trials and most successful open-label trails performed previously, tissue chunks or "noodles" were used, in place of cell suspensions, cells were stored in culture prior to administration to document dopamine production, and use of immunosuppression was minimized. Novel animal models incompletely simulating human dyskinesias were developed and analyzed in detail to try to tease apart the causes of the adverse outcomes. Leading hypotheses ultimately implicated the presence of "hot-spots" due to uneven distribution of cells, and contamination of problematic grafts with higher numbers of serotonergic neurons in the development of dyskinesias (Lane et al., 2010).

Meanwhile, in the decade following the cessation of clinical trials, it was observed that certain patients previously implanted using the original protocols remained alive and well, in some cases off all anti-Parkinson's medications and with sustained improvement in motor performance, even up to 18 years after transplantation (Kefalopoulou et al., 2014). The favorable clinical course of such patients has thus offered hope that with optimized protocols, cellular therapy could conceivably alter the natural history of Parkinson's disease in appropriately selected patients. As such, TRANSEURO, a randomized controlled trial of fetal cell therapies was recently launched incorporating the lessons of prior experience (Abbott, 2014). In addition, based on excellent progress in preclinical studies in rodents and primates using human ESC- and iPSC-derived cells (Ganat et al., 2012; Kriks et al., 2011; Sundberg et al., 2013), it is anticipated that trials of human stem-cell-derived dopaminergic neurons will be initiated in the near future.

\subsection{Bone marrow for stroke}

Given the clearly defined etiology of ischemic stroke (acute lack of blood supply to the brain with or without delayed reperfusion), animal models of stroke are easily generated and well defined. Despite this, neuroprotective therapies effective in preclinical studies have almost universally failed in clinical trials of stroke. Potential reasons for this have been widely reviewed (Gladstone et al., 2002; O'Collins et al., 2006; van der Worp et al., 2005; van der Worp et al., 2010); See also Table 2. Among the most frequently cited "problems" are: (1) Most preclinical studies are performed in mice and rats, rather than animals phylogenetically closer to humans. (2) Most studies include young healthy animals whereas patients suffering stroke are more frequently elderly and suffer comorbidities such as hypertension and diabetes. (3) Unrealistic time points for intervention are frequently used. Indeed, in a systematic review of animal studies of 5 neuroprotective agents tested in 21 clinical trials involving $>12,000$ patients, the median time between onset of ischemia and start of treatment was $10 \mathrm{~min}$. By contrast, patients very rarely arrive at the hospital within $1 \mathrm{~h}$ (Lacy et al., 2001; Leon-Jimenez et al., 2014). (4) Different outcome measures are used in preclinical and clinical studies. For example, outcome assessments in animal models have historically been performed just days following therapy, rather than months after therapy, as occurs in human trials (van der Worp et al., 2005). In addition, infarct size, frequently evaluated in preclinical studies, is rarely assessed in clinical trials, and appears to poorly correlate with functional outcomes. (5) Animal studies of stroke have exemplified systemic problems of lack of appropriate randomization, blinding, and publication bias (Sena et al., 2010; van der Worp et al., 2010). (6) Inappropriate extrapolation of rodent studies when calculating sample sizes for clinical trials may further result in some potentially beneficial compounds being labeled as "failures" due to insufficient power. (7) Finally, it should be considered that "failed" compounds could still be useful as a component of polytherapy, even if ineffective in adequately powered clinical trials of monotherapy (Gladstone et al., 2002).
As promising cell therapies for stroke have moved toward clinical trials, there has been strong motivation to circumvent the prior failures experienced with neuroprotective compounds. As such, the STEPS (Stem Cells as an Emerging Paradigm in Stroke) consortium has published guidelines and research priorities to facilitate successful translation of cellular stroke therapies (Savitz et al., 2011; Savitz et al., 2014; Stem Cell, 2009).

Outcomes in hundreds of preclinical studies for stroke have now been analyzed by multiple meta-analyses, revealing insights into numerous variables. Overall, findings to date suggest substantial benefits in animal models across a variety of cell types, post-infarct time periods, and delivery strategies. A recent metaanalysis by $\mathrm{Vu}$ et al. (2014) suggested that perhaps the greatest improvement in modified neurological severity score was seen with intracerebral, followed by intra-arterial, followed by intravenous delivery $(p=0.025)$. Yet, even the benefit from intravenous delivery was regarded as "very large" . Encouragingly for translational efforts, the greatest reduction in infarct size was seen in primates, followed by rats and then mice, though the number of primate studies to date has remained small. Interestingly, human cells, appeared more effective at reducing infarct volume even in rodents, than rat cells, with mouse cells proving the least effective $(p=0.036)$.

Poor correlation between infarct size and functional outcomes has previously been reported in both humans and animal models. Consistent with this idea, a meta-analysis of preclinical studies found autologous cells to be the most helpful in reducing infarct size, while allogeneic cells yielded the greatest benefits in functional outcome (Lees et al., 2012). Furthermore, Vu et al. suggested that infarct size was most significantly reduced with early cell delivery $(0-8 \mathrm{~h})(p=0.038)$; however, the greatest improvement in rotarod performance occurred when cells were delivered $>24 \mathrm{~h}$ after infarct $(p<0.004)$. Though seemingly contradictory, these data may suggest that MSCs have the potential to both reduce damage and promote repair, and that a wide therapeutic window exists for MSCs to promote functional improvement. While concerns of under-reported negative studies cloud meta-analyses of preclinical data, the findings to date have been overwhelmingly and consistently positive.

Acknowledging the limited role for cell replacement in stroke therapy, bone-marrow-derived cells have emerged as the favored candidate for stroke therapy. Indeed, the relative accessibility of bone-marrow-derived cells, including bone marrow mononuclear cells (BMMCS) and MSCs, has perhaps contributed to the rapid proliferation of early-stage clinical trials of cell therapy for stroke (Doeppner and Hermann, 2014). While most clinical studies to date have been non-randomized safety studies, one randomized open-label observer-blinded trial of autologous MSCs showed improved survival and outcomes at 5 years following intravenous delivery of autologous MSCs at 1 and 2 months after stroke (Lee et al., 2010). These data are consistent with a preliminary metaanalysis of outcomes in single-arm studies of MSCs for stroke that suggest highly significant improvements from baseline of 5.7 points on the National Institutes of Health Stroke Scale (NIHSS) and 31.5 points on the Barthel Index.

By contrast, a multicenter randomized trial failed to demonstrate significant benefit from a single intravenous administration of autologous BMMNCs (Prasad et al., 2014). Although further studies are needed to validate these results, the negative results in this first randomized trial of IV BMMNCs for stroke are consistent with a meta-analysis of 8 clinical trials administering granulocyte colony-stimulating factor (G-CSF)-used in part to mobilize BMMNCs-which yielded non-significant improvements at early time points and no difference in outcomes at later time points (Bath et al., 2013). In a meta-analysis of preclinical studies employing IV delivery of cells for stroke, MSCs were found to be 
Table 2

Hypothetical illustration of typical trials for stroke, illustrating challenges in translation. about twice as efficacious as BMMNCs (Janowski et al., 2010). Such differences in efficacy may not be limited to the brain. In a randomized blinded placebo-controlled trial of intra-arterially delivered cells for ischemic cardiomyopathy, culture-expanded MSCs proved more efficacious than bone marrow mononuclear cells for enhancing left ventricular ejection fraction (Heldman et al., 2014). Nevertheless, careful optimization of protocols may be needed even among MSCs. For example Li et al. (2008a) reported greater improvement in endogenous neurogenesis and behavioral recovery in rats treated with passage 2 rather than passage 6 MSCs.

As additional data emerge from clinical trials, it will be important to evaluate what subsets of patients might specifically benefit from cell therapy. The integrity of critical white matter tracts, such as corticospinal tracts, may dictate maximal recovery potential, providing a better predictor of outcome than baseline neurological exam after stroke (Chen et al., 2004; Stinear and Byblow, 2014). The role of physical rehabilitation in accelerating this recovery, or potentially even raising the ultimate predicted plateau remains under active investigation. Interactions between stem cell therapy and these variables may prove to be of great importance in future studies (Savitz et al., 2014; Teasell et al., 2012).

\subsection{Spinal cord injury}

Spinal cord injury (SCI) remains one of the most frequently cited "hopes" for successful stem cell therapy. Although the need to "regrow" axons is frequently assumed for SCI, spinal cord contusion is actually much more common than spinal cord transection, leading in part to a demyelinating injury to corticospinal tracts. As such, strategies to restore myelination following SCI have been intensively investigated. Positive results in rodent models of SCI using oligodendrocyte precursor cells (OPCs) prompted the well-publicized, but prematurely terminated Geron trial of human ESC-derived OPCs for complete thoracic SCI. Asterias Biotherapeutics, Inc. has now acquired all assets related to the project and a follow-up phase $1 / 2$ trial for complete cervical SCI is expected to begin in 2015 (NCT02302157). Neural Stem Cells were previously shown to promote remyelination in brains of pediatric patients with Pelizaeus-Merzbacher disease, a rare lysosome storage disorder (Gupta et al., 2012), and are now similarly being tested in multiple trials for thoracic spinal cord injury in the US, Canada and Europe.
Overlapping mechanisms of hypoxic injury and neuro-inflammation, with glial and microglial activation, characterize both $\mathrm{SCI}$ and stroke. A resulting glial scar, which serves to restrict the scope of injury, leads to a lasting obstructive barrier to neurite outgrowth. As with stem cell therapies for stroke, MSCs have been investigated in preclinical models of SCI. A recent meta-analysis of 80 rat studies employing MSCs for SCI demonstrated a highly significant benefit across a variety of MSC sources, and immunosuppression and delivery protocols (Oliveri et al., 2014). Although the influence of under-reported negative data are again difficult to fully exclude, the combined results performed extremely well on a proposed grading scheme to objectively evaluate the strength of preclinical data for clinical translation in $\mathrm{SCI}$, and higher than any drug previously evaluated on the same scale (Kwon et al., 2011). Another meta-analysis of cellular therapies including 156 studies and 5628 animals revealed an overall $27.2 \%$ improvement (95\% CI 25.0-29.4\%) in motor function (Antonic et al., 2013) with cell therapy. Intravenous therapy provided the greatest benefit when compared to cell therapy directly administered into the spinal cord, perhaps in part due to the challenges of cell delivery in the tiny rodent spinal cord. Interestingly, Greatest benefit was seen in animals treated with isoflurane, perhaps suggesting the potential for interactions between stem cell therapy and other neuroprotective interventions. Numerous clinical trials employing MSCs for spinal cord injury are ongoing (Martinez et al., 2014).

The attitudes of patients with SCI towards participation in a stem cell clinical trial have been surveyed in detail. Over half of patients indicated they definitely or probably would be willing to participate in a stem trial for subacute (57\%) or chronic (66\%) SCI, compared to $87 \%$ who would be willing to participate in an acute drug trial. Importantly, the most common reason cited by $71-74 \%$ of patients who said they "definitely" or "probably" would not participate in a stem cell trial was "don't want to risk getting cancer," followed by "don't want to have another surgery" (58-63\% of patients) (Kwon et al., 2012). These findings underscore the critical obligation of the scientific community to ensure the safety of administered cellular therapeutics. To date, there is no replacement for preclinical animal models to ensure the safety of cell therapies advanced to clinical trials. In the clinical trials to date for spinal cord injury, no safety concerns have arisen, though insufficient data exist to extrapolate efficacy data from rodents to humans. 


\subsection{ALS}

If spinal cord injury is unique, based on the youth and longevity of its victims, ALS is unique among neurodegenerative disease for its relatively rapid loss of susceptible motor and corticospinal neurons, leading to weakness and death typically from respiratory failure.

SOD1G93A mice are widely considered the gold standard model for ALS. However, similar to animal models for other neurodegenerative diseases, this model has been criticized for poorly representing human disease. Indeed, this mutation is present in only $3 \%$ of patients with ALS, and the mice carry 23 copies of the gene. As such successful therapies in this mouse model may be inappropriately skewed towards blockade of SOD1, which may be of questionable value for human ALS (van der Worp et al., 2010). Among other problems, a high degree of noise in the SOD1G93A model has been suggested to explain the majority of successful reports describing prolonged survival with various drugs. Attempts to replicate positive findings for 8 compounds (minocycline, creatine, celecoxib, sodium phenylbutyrate, ceftriaxone, WHI-P131, thalidomide, and riluzole) using optimal methods to reduce noise failed to demonstrate survival benefit with any of the 8 compounds. Such optimized methods included: (1) large group sizes of at least 24 litter-matched gender balanced mice; (2) exclusion of nonALS deaths and low-copy transgenics and, when applicable, exclusion also of the corresponding paired animal from the comparison group; (3) blinded analysis using a single uniform endpoint criterion (inability to right itself in $30 \mathrm{~s}$ after being placed on its side); (4) analysis of survival using appropriate multivariate statistical models (Scott et al., 2008).

It is against such elevated standards that cell therapies for ALS are now being assessed in preclinical studies. A meta-analysis of 11 studies by members of the ALS consortium revealed improved function and prolonged survival after intraspinal delivery of human or mouse NSCs into SOD1G93A mice (Teng et al., 2012). Maximal benefit was seen when NSCs were injected at multiple sites along the neuroaxis including the lumbar, thoracic and cervical spine-a finding replicated with both mouse and human NSCs. Indeed administration of 100,000 murine NSCs (mNSCs) into 4 locations resulted in improved rotor-rod performance and prolonged survival with $25 \%$ of animals surviving more than 1 year (Teng et al., 2012)-well beyond that see in any previously tested pharmacological therapy (Scott et al., 2008). Although the mechanisms of action remain incompletely understood, transplanted cells were found to produce trophic factors such as glialcell-derived neurotrophic factor (GDNF), decrease astrogliosis, increase the number of surviving motor neurons, and preserve the neuromuscular junction (Teng et al., 2012), consistent with previously reported findings in ALS rats (Xu et al., 2006; Yan et al., 2007).

Collectively, these and other preclinical findings suggest that cell therapy may offer unprecedented potential to alter the natural history of ALS. Prior to translation of NSC therapy to humans, the Boulis group employed a porcine model to optimize the technical delivery of cells into the fragile spinal cord. Given that the spinal cord moves slightly during surgery with respiration, the porcine model facilitated development of a novel delivery apparatus employing a "floating needle" strategy (Federici et al., 2012). In human phase 1 studies, apparent stabilization of the clinical course in 3 patients who received the highest numbers of NSCs into the cervical cord provides hope, albeit not clear evidence of efficacy in humans (Feldman et al., 2014). Although putative graft-derived cells lacking neuronal and glial markers were identified, the presence of graft-derived neurons or glia could not be evaluated from these experiments using unlabeled human cells. A phase 2 trial with higher cell numbers is ongoing.

MSCs are also under clinical investigation for ALS via both intracerebral (Martinez et al., 2009) and intrathecal (Kim et al., 2014) delivery. In one study, autologous MSC cultures from ALS patients demonstrating the most favorable response to implantation of their own cells were evaluated and found to produce higher levels of vascular endothelial growth factor (VEGF), angiogenin and TGF- $\beta$ than those of patients who did not improve after autologous cell therapy. Interestingly, MSCs from one patient with a favorable response to autologous MSCs were tested in SOD1 mice and found to prolong survival more than MSCs from patients who had failed to improve, illustrating the potential of animal models to help evaluate clinical observations as trials progress (Kim et al., 2014). The reader is referred to other more comprehensive reviews for additional details regarding ongoing cell therapy trials for ALS (Antonic et al., 2013; Donnelly et al., 2012; Faravelli et al., 2014; Thomsen et al., 2014)

\subsection{Early steps in Alzheimer's disease}

Alzheimer's disease is by far the most common neurodegenerative disorder. Its great socioeconomic toll makes therapies against Alzheimer's disease a key scientific and public health priority, though translational progress to date has been limited. A great variety of animal models of Alzheimer's have been developed, yet none encapsulate all the cardinal features of Alzheimer's including neurofibrillary tangles, amyloid plaques, neuronal loss and cognitive decline (Cavanaugh et al., 2014; Franco and Cedazo-Minguez, 2014; Neha et al., 2014). To date, animal studies of various cell populations including NSCs and MSCs among others, have yielded favorable results, including improved cognitive performance, decreased amyloid-beta deposition, increased acetylcholine levels and immune modulation in multiple models of AD mice (Choi et al., 2014). In a small pilot clinical study, nerve growth factor(NGF)-overexpressing immortalized human pigment epithelial cells were stereotactically delivered to the basal forebrain in retrievable encapsulation devices (Wahlberg et al., 2012). This work followed from studies demonstrating robust long-term NGF delivery in Gottinberg minipigs (Fjord-Larsen et al., 2010), though lower survival of the encapsulated cells was seen after retrieval of the devices from human brains (Wahlberg et al., 2012). Preliminary clinical results demonstrated less brain shrinkage than expected based on historical MMSE-matched controls in a subset of patients (Ferreira et al., 2015), though results at this point should be considered very preliminary. Additional clinical trials employing MSCs are in progress or planned (NCT01297218, NCT02054208, NCT01547689). If exposure to young plasma proves sufficient to induce CNS rejuvenation in Alzheimer's patients (NCT02256306) as shown in aged mice (Villeda et al., 2014), one goal of future cell therapies may be to augment the supply of identified "youthful" factors required for CNS resilience against age-related stress.

Active work is additionally ongoing to investigate cellular therapies for multiple sclerosis (Ferreira et al., 2015; Martino et al., 2010), Huntington's disease(Olson et al., 2012), traumatic brain injury (Richardson et al., 2010; Xiong et al., 2013) and epilepsy, (Roper and Steindler, 2013), and pediatric lysosomal storage diseases (Gupta et al., 2012; Selden et al., 2013), among others. Indeed, cell therapies may not be limited to CNS injuries or degeneration but are also under investigation to help combat brain tumors due to their migratory behavior, inherent anti-tumorgenic properties, and capacity to deliver genes, prodrugs or oncolytic viruses to sites of tumor infiltration (Bovenberg et al., 2013).

\section{Conclusions}

Despite their mechanistic limitations, animal models are indispensable for translation of neuroregenerative therapies. Failure of animal models to precisely mirror the early mechanistic changes underlying most human neurodegenerative diseases has hampered the successful translation of targeted pharmaceuticals. Real-world human neurological diseases are heterogeneous and manifest as the culmination of multiple genetic and environmental variables 
compounded by age and stress. As such, therapies likely to be successful in more than a small subset of patients must synergistically impact multiple pathways of disease. To this end, as nature's own multipotent agents of repair, endogenous progenitor cells are now known to be working behind the scenes to mitigate CNS injury. Indeed, given their multiple modes of action, stem-cell-based therapies may be less susceptible to mechanistic inaccuracies of preclinical animal models, and more amenable to successful translation in diseases for which the underlying etiologies are heterogeneous or remain poorly understood. As understanding of human disease mechanisms improves, cell-based therapies may provide a regenerative platform upon which further enhancements can be built. Studies of rejuvenation may reveal mechanisms of youthful reliance, whose decline leaves the brain open to degeneration, but which could be replenished to help the CNS combat injury and degeneration. While success will require that the field learn from its prior and future mistakes whilst stringently adhering to evolving best practices in pre-clinical and clinical studies, neuroregenerative strategies offer substantive hope for mice, scientists and patients alike.

\section{Acknowledgments}

We thank Cindy Samos for Editorial Assistance. Funding support was provided by the California Institute of Regenerative Medicine (TCB).

\section{References}

Abbott, A., 2014. Fetal-cell revival for Parkinson's. Nature 510, 195-196.

Alonso, M., Lepousez, G., Sebastien, W., Bardy, C., Gabellec, M.M., Torquet, N., Lledo P.M., 2012. Activation of adult-born neurons facilitates learning and memory. Nat. Neurosci. 15, 897-904.

Alonso, M., Viollet, C., Gabellec, M.M., Meas-Yedid, V., Olivo-Marin, J.C., Lledo, P.M., 2006. Olfactory discrimination learning increases the survival of adult-born neurons in the olfactory bulb. J. Neurosci.: Off. J. Soc. Neurosci. 26, 10508-10513.

Altman, J., Das, G.D., 1965a. Autoradiographic and histological evidence of postnatal hippocampal neurogenesis in rats. J. Comp. Neurol. 124, 319-335.

Altman, J., Das, G.D., 1965b. Post-natal origin of microneurones in the rat brain. Nature 207, 953-956.

Amariglio, N., Hirshberg, A., Scheithauer, B.W., Cohen, Y., Loewenthal, R., Trakhtenbrot, L., Paz, N., Koren-Michowitz, M., Waldman, D., Leider-Trejo, L., Toren, A. Constantini, S., Rechavi, G., 2009. Donor-derived brain tumor following neural stem cell transplantation in an ataxia telangiectasia patient. PLoS Med. 6, e1000029.

Antonic, A., Sena, E.S., Lees, J.S., Wills, T.E., Skeers, P., Batchelor, P.E., Macleod, M.R., Howells, D.W., 2013. Stem cell transplantation in traumatic spinal cord injury: a systematic review and meta-analysis of animal studies. PLoS Biol. 11, e1001738.

Aranguren, X.L., McCue, J.D., Hendrickx, B., Zhu, X.H., Du, F., Chen, E., Pelacho, B., Penuelas, I., Abizanda, G., Uriz, M., Frommer, S.A., Ross, J.J., Schroeder, B.A., Seaborn, M.S., Adney, J.R., Hagenbrock, J., Harris, N.H., Zhang, Y., Zhang, X., Nelson-Holte, M.H., Jiang, Y., Billiau, A.D., Chen, W., Prosper, F., Verfaillie, C.M., Luttun, A., 2008. Multipotent adult progenitor cells sustain function of ischemic limbs in mice. J. Clin. Investig. 118, 505-514.

Barker, R.A., Barrett, J., Mason, S.L., Bjorklund, A., 2013. Fetal dopaminergic transplantation trials and the future of neural grafting in Parkinson's disease. Lancet. Neurol. 12, 84-91.

Bath, P.M., Sprigg, N., England, T., 2013. Colony stimulating factors (including erythropoietin, granulocyte colony stimulating factor and analogues) for stroke. Cochrane Database Syst. Rev. 6.

Benraiss, A., Toner, M.J., Xu, Q. Bruel-Jungerman, E., Rogers, E.H., Wang, F., Economides, A.N., Davidson, B.L., Kageyama, R., Nedergaard, M., Goldman, S. A., 2013. Sustained mobilization of endogenous neural progenitors delays disease progression in a transgenic model of Huntington's disease. Cell Stem Cell12, 787-799.

Bherer, L., Erickson, K.I., Liu-Ambrose, T., 2013. A review of the effects of physical activity and exercise on cognitive and brain functions in older adults. J. Aging Res. 2013, 657508

Bjorklund, A., 1992. Dopaminergic transplants in experimental parkinsonism: cellular mechanisms of graft-induced functional recovery. Curr. Opin. Neurobiol. 2, 683-689.

Bjorklund, A., Stenevi, U., Svendgaard, N., 1976. Growth of transplanted monoaminergic neurones into the adult hippocampus along the perforant path. Nature 262, 787-790.

Bovenberg, M.S., Degeling, M.H., Tannous, B.A., 2013. Advances in stem cell therapy against gliomas. Trends Mol. Med. 19, 281-291.
Burns, T.C., Li, M.D., Mehta, S., Awad, A.J., Morgan, A.A., 2015. Mouse models rarely mimic the transcriptome of human neurodegenerative diseases: a systematic bioinformatics-based critique of preclinical models. Eur. J. Pharmacol., xx, xx.

Burns, T.C., Ortiz-Gonzalez, X.R., Gutierrez-Perez, M., Keene, C.D., Sharda, R., Demorest, Z.L., Jiang, Y., Nelson-Holte, M., Soriano, M., Nakagawa, Y., Luquin, M.R. Garcia-Verdugo, J.M., Prosper, F., Low, W.C., Verfaillie, C.M., 2006. Thymidine analogs are transferred from prelabeled donor to host cells in the central nervous system after transplantation: a word of caution. Stem Cells 24, 1121-1127.

Burns, T.C., Steinberg, G.K., 2011. Stem cells and stroke: opportunities, challenges and strategies. Expert Opin. Biol. Ther. 11, 447-461.

Burns, T.C., Verfaillie, C.M., Low, W.C., 2009. Stem cells for ischemic brain injury: a critical review. J. Comp. Neurol. 515, 125-144.

Cavanaugh, S.E., Pippin, J.J., Barnard, N.D., 2014. Animal models of Alzheimer disease: historical pitfalls and a path forward. ALTEX 31, 279-302.

Chen, J., Magavi, S.S., Macklis, J.D., 2004. Neurogenesis of corticospinal motor neurons extending spinal projections in adult mice. Proc. Natl. Acad. Sci. USA $101,16357-16362$.

Choi, S.S., Lee, S.R., Kim, S.U., Lee, H.J., 2014. Alzheimer's disease and stem cell therapy. Exp. Neurobiol. 23, 45-52.

Curtis, M.A., Kam, M., Nannmark, U., Anderson, M.F., Axell, M.Z., Wikkelso, C., Holtas, S., van Roon-Mom, W.M., Bjork-Eriksson, T., Nordborg, C., Frisen, J., Dragunow, M., Faull, R.L., Eriksson, P.S., 2007. Human neuroblasts migrate to the olfactory bulb via a lateral ventricular extension. Science 315, 1243-1249.

Dauer, W., Przedborski, S., 2003. Parkinson's disease: mechanisms and models. Neuron 39, 889-909.

de Chevigny, A., Cooper, O., Vinuela, A., Reske-Nielsen, C., Lagace, D.C., Eisch, A.J., Isacson, O., 2008. Fate mapping and lineage analyses demonstrate the production of a large number of striatal neuroblasts after transforming growth factor alpha and noggin striatal infusions into the dopamine-depleted striatum. Stem Cells26, 2349-2360.

Dlouhy, B.J., Awe, O., Rao, R.C., Kirby, P.A., Hitchon, P.W., 2014. Autograft-derived spinal cord mass following olfactory mucosal cell transplantation in a spinal cord injury patient: case report. J. Neurosurg. Spine 21, 618-622.

Doeppner, T.R., Hermann, D.M., 2014. Stem cell-based treatments against stroke: observations from human proof-of-concept studies and considerations regarding clinical applicability. Front. Cell. Neurosci. 8, 357.

Donnelly, E.M., Lamanna, J., Boulis, N.M., 2012. Stem cell therapy for the spinal cord. Stem Cell Res. Ther.3, 24.

Doody, R.S., Thomas, R.G., Farlow, M., Iwatsubo, T., Vellas, B., Joffe, S., Kieburtz, K., Raman, R., Sun, X., Aisen, P.S., Siemers, E., Liu-Seifert, H., Mohs, R., 2014. Alzheimer's disease cooperative study steering, C., solanezumab study, G phase 3 trials of solanezumab for mild-to-moderate Alzheimer's disease. N. Engl. J. Med. 370, 311-321.

Draganski, B., Gaser, C., Kempermann, G., Kuhn, H.G., Winkler, J., Buchel, C., May, A., 2006. Temporal and spatial dynamics of brain structure changes during extensive learning. J. Neurosci. Off. J. Soc. Neurosci. 26, 6314-6317.

Eriksson, P.S., Perfilieva, E., Bjork-Eriksson, T., Alborn, A.M., Nordborg, C., Peterson, D.A., Gage, F.H., 1998. Neurogenesis in the adult human hippocampus. Nat. Med. 4, 1313-1317.

Ernst, A., Alkass, K., Bernard, S., Salehpour, M., Perl, S., Tisdale, J., Possnert, G., Druid, H., Frisen, J., 2014. Neurogenesis in the striatum of the adult human brain. Cell 156, 1072-1083.

Faravelli, I., Riboldi, G., Nizzardo, M., Simone, C., Zanetta, C., Bresolin, N., Comi, G.P., Corti, S., 2014. Stem cell transplantation for amyotrophic lateral sclerosis: therapeutic potential and perspectives on clinical translation. Cell. Mol. Life Sci. 71, 3257-3268.

Federici, T., Hurtig, C.V., Burks, K.L., Riley, J.P., Krishna, V., Miller, B.A., Sribnick, E.A., Miller, J.H., Grin, N., Lamanna, J.J., Boulis, N.M., 2012. Surgical technique for spinal cord delivery of therapies: demonstration of procedure in gottingen minipigs. J. Vis. Exp., e4371.

Feldman, E.L., Boulis, N.M., Hur, J., Johe, K., Rutkove, S.B., Federici, T., Polak, M., Bordeau, J., Sakowski, S.A., Glass, J.D., 2014. Intraspinal neural stem cell transplantation in amyotrophic lateral sclerosis: phase 1 trial outcomes. Ann. Neurol. 75, 363-373.

Ferreira, D., Westman, E., Eyjolfsdottir, H., Almqvist, P., Lind, G., Linderoth, B., Seiger, A., Blennow, K., Karami, A., Darreh-Shori, T., Wiberg, M., Simmons, A., Wahlund, L.O., Wahlberg, L., Eriksdotter, M., 2015. Brain changes in Alzheimer's disease patients with implanted encapsulated cells releasing nerve growth factor. J. Alzheimer's Dis. 43, 1059-1072.

Fjord-Larsen, L., Kusk, P., Tornoe, J., Juliusson, B., Torp, M., Bjarkam, C.R., Nielsen, M. S., Handberg, A., Sorensen, J.C., Wahlberg, L.U., 2010. Long-term delivery of nerve growth factor by encapsulated cell biodelivery in the Gottingen minipig basal forebrain. Mol. Ther. J. Am. Soc. Gene Ther. 18, 2164-2172.

Franco, R., Cedazo-Minguez, A., 2014. Successful therapies for Alzheimer's disease: why so many in animal models and none in humans? Front. Pharmacol. 5, 146.

Franklin, R.J., Ffrench-Constant, C., 2008. Remyelination in the CNS: from biology to therapy. Nat. Rev. Neurosci. 9, 839-855.

Freed, C.R., Greene, P.E., Breeze, R.E., Tsai, W.Y., DuMouchel, W., Kao, R., Dillon, S., Winfield, H., Culver, S., Trojanowski, J.Q., Eidelberg, D., Fahn, S., 2001. Transplantation of embryonic dopamine neurons for severe Parkinson's disease. N. Engl. J. Med. 344, 710-719.

Ganat, Y.M., Calder, E.L., Kriks, S., Nelander, J., Tu, E.Y., Jia, F., Battista, D., Harrison, N., Parmar, M., Tomishima, M.J., Rutishauser, U., Studer, L., 2012. Identification of embryonic stem cell-derived midbrain dopaminergic neurons for engraftment. J. Clin. Investig. 122, 2928-2939. 
Gibson, E.M., Purger, D., Mount, C.W., Goldstein, A.K., Lin, G.L., Wood, L.S., Inema, I., Miller, S.E., Bieri, G., Zuchero, J.B., Barres, B.A., Woo, P.J., Vogel, H., Monje, M., 2014. Neuronal activity promotes oligodendrogenesis and adaptive myelination in the mammalian brain. Science $344,1252304$.

Gladstone, D.J., Black, S.E., Hakim, A.M., 2002. Heart, stroke foundation of ontario centre of excellence in stroke, toward wisdom from failure: lessons from neuroprotective stroke trials and new therapeutic directions. Stroke: J. Cereb. Circ. 33, 2123-2136.

Goldman, S.A., Nottebohm, F., 1983. Neuronal production, migration, and differentiation in a vocal control nucleus of the adult female canary brain. Proc. Natl. Acad. Sci. USA 80, 2390-2394.

Gupta, N., Henry, R.G., Strober, J., Kang, S.M., Lim, D.A., Bucci, M., Caverzasi, E., Gaetano, L., Mandelli, M.L., Ryan, T., Perry, R., Farrell, J., Jeremy, R.J., Ulman, M. Huhn, S.L., Barkovich, A.J., Rowitch, D.H., 2012. Neural stem cell engraftment and myelination in the human brain. Sci. Transl. Med. 4 155ra137.

Hartley, M.D., Altowaijri, G., Bourdette, D., 2014. Remyelination and multiple sclerosis: therapeutic approaches and challenges. Curr. Neurol. Neurosci. Rep.14, 485

Heinrich, C., Bergami, M., Gascon, S., Lepier, A., Vigano, F., Dimou, L., Sutor, B. Berninger, B., Gotz, M. 2014. Sox2-mediated conversion of NG2 Glia into induced neurons in the injured adult cerebral cortex. Stem Cell Rep. 3, 1000-1014.

Heinrich, C., Blum, R., Gascon, S., Masserdotti, G., Tripathi, P., Sanchez, R., Tiedt, S. Schroeder, T., Gotz, M., Berninger, B., 2010. Directing astroglia from the cerebral cortex into subtype specific functional neurons. PLoS Biol. 8, e1000373.

Heldman, A.W., DiFede, D.L., Fishman, J.E., Zambrano, J.P., Trachtenberg, B.H., Karantalis, V., Mushtaq, M. Williams, A.R., Suncion, V.Y., McNiece, I.K., Ghersin, E., Soto, V., Lopera, G., Miki, R., Willens, H., Hendel, R., Mitrani, R., Pattany, P., Feigenbaum, G., Oskouei, B., Byrnes, J., Lowery, M.H., Sierra, J., Pujol, M.V., Delgado, C., Gonzalez, P.J., Rodriguez, J.E., Bagno, L.L., Rouy, D., Altman, P., Foo, C. W., da Silva, J., Anderson, E., Schwarz, R., Mendizabal, A., Hare, J.M., 2014. Transendocardial mesenchymal stem cells and mononuclear bone marrow cells for ischemic cardiomyopathy: the TAC-HFT randomized trial. JAMA 311, 62-73.

Huttner, H.B., Bergmann, O., Salehpour, M., Racz, A., Tatarishvili, J., Lindgren, E., Csonka, T., Csiba, L., Hortobagyi, T., Mehes, G., Englund, E., Solnestam, B.W., Zdunek, S., Scharenberg, C., Strom, L., Stahl, P., Sigurgeirsson, B., Dahl, A. Schwab, S., Possnert, G., Bernard, S., Kokaia, Z., Lindvall, O., Lundeberg, J., Frisen, J., 2014. The age and genomic integrity of neurons after cortical stroke in humans. Nat. Neurosci. 17, 801-803.

Imayoshi, I., Sakamoto, M., Ohtsuka, T., Takao, K., Miyakawa, T., Yamaguchi, M., Mori, K., Ikeda, T., Itohara, S., Kageyama, R., 2008. Roles of continuous neurogenesis in the structural and functional integrity of the adult forebrain. Nat. Neurosci. 11, 1153-1161.

Janowski, M., Walczak, P., Date, I., 2010. Intravenous route of cell delivery for treatment of neurological disorders: a meta-analysis of preclinical results. Stem Cells Dev. 19, 5-16.

Jeong, J.O., Han, J.W., Kim, J.M., Cho, H.J., Park, C., Lee, N., Kim, D.W., Yoon, Y.S., 2011. Malignant tumor formation after transplantation of short-term cultured bone marrow mesenchymal stem cells in experimental myocardial infarction and diabetic neuropathy. Circ. Res. 108, 1340-1347.

Jessberger, S., Gage, F.H., 2014. Adult neurogenesis: bridging the gap between mice and humans. Trends Cell Biol. 24, 558-563.

Karow, M., Sanchez, R., Schichor, C., Masserdotti, G., Ortega, F., Heinrich, C., Gascon, S., Khan, M.A., Lie, D.C., Dellavalle, A., Cossu, G., Goldbrunner, R., Gotz, M., Berninger, B., 2012. Reprogramming of pericyte-derived cells of the adult human brain into induced neuronal cells. Cell Stem Cell 11, 471-476.

Kefalopoulou, Z., Politis, M., Piccini, P., Mencacci, N., Bhatia, K., Jahanshahi, M. Widner, H., Rehncrona, S., Brundin, P., Bjorklund, A., Lindvall, O., Limousin, P. Quinn, N., Foltynie, T., 2014. Long-term clinical outcome of fetal cell transplantation for Parkinson disease: two case reports. JAMA Neurol. 71, 83-87.

Kim, H.Y., Kim, H., Oh, K.W., Oh, S.I., Koh, S.H., Baik, W., Noh, M.Y., Kim, K.S., Kim, S. H., 2014. Biological markers of mesenchymal stromal cells as predictors of response to autologous stem cell transplantation in patients with amyotrophic lateral sclerosis: an investigator-initiated trial and in vivo study. Stem Cells 32, 2724-2731.

Kim, J.H., Auerbach, J.M., Rodriguez-Gomez, J.A., Velasco, I., Gavin, D., Lumelsky, N., Lee, S.H., Nguyen, J., Sanchez-Pernaute, R., Bankiewicz, K., McKay, R., 2002. Dopamine neurons derived from embryonic stem cells function in an animal model of Parkinson's disease. Nature 418, 50-56.

Kojima, T., Hirota, Y., Ema, M., Takahashi, S., Miyoshi, I., Okano, H., Sawamoto, K., 2010. Subventricular zone-derived neural progenitor cells migrate along a blood vessel scaffold toward the post-stroke striatum. Stem Cells28, 545-554.

Kornack, D.R., Rakic, P., 2001. The generation, migration, and differentiation of olfactory neurons in the adult primate brain. Proc. Natl. Acad. Sci. USA 98, $4752-4757$.

Kriks, S., Shim, J.W., Piao, J., Ganat, Y.M., Wakeman, D.R., Xie, Z., Carrillo-Reid, L., Auyeung, G., Antonacci, C., Buch, A., Yang, L., Beal, M.F., Surmeier, D.J., Kordower, J.H., Tabar, V., Studer, L., 2011. Dopamine neurons derived from human ES cells efficiently engraft in animal models of Parkinson's disease. Nature 480, 547-551.

Krstic, D., Knuesel, I., 2013. The airbag problem-a potential culprit for bench-tobedside translational efforts: relevance for Alzheimer's disease. Acta Neuropathol. Commun. 1, 62.

Kwon, B.K., Ghag, A., Dvorak, M.F., Tetzlaff, W., Illes, J., 2012. Expectations of benefit and tolerance to risk of individuals with spinal cord injury regarding potential participation in clinical trials. J. Neurotrauma 29, 2727-2737.
Kwon, B.K., Okon, E.B., Tsai, E., Beattie, M.S., Bresnahan, J.C., Magnuson, D.K., Reier, P.J., McTigue, D.M., Popovich, P.G., Blight, A.R., Oudega, M., Guest, J.D., Weaver, L C., Fehlings, M.G., Tetzlaff, W., 2011. A grading system to evaluate objectively the strength of pre-clinical data of acute neuroprotective therapies for clinica translation in spinal cord injury. J. Neurotrauma 28, 1525-1543.

Lacy, C.R., Suh, D.C., Bueno, M., Kostis, J.B., 2001. Delay in presentation and evaluation for acute stroke: stroke Time Registry for Outcomes Knowledge and Epidemiology (S.T.R.O.K.E.). Stroke J. Cereb. Circ. 32, 63-69.

Lane, E.L., Bjorklund, A., Dunnett, S.B., Winkler, C., 2010. Neural grafting in Parkinson's disease unraveling the mechanisms underlying graft-induced dyskinesia. Prog. Brain Res. 184, 295-309.

Lee, H.K., Finniss, S., Cazacu, S., Bucris, E., Ziv-Av, A., Xiang, C., Bobbitt, K., Rempel, S. A., Hasselbach, L., Mikkelsen, T., Slavin, S., Brodie, C., 2013. Mesenchymal stem cells deliver synthetic microRNA mimics to glioma cells and glioma stem cells and inhibit their cell migration and self-renewal. Oncotarget 4, 346-361.

Lee, J.S., Hong, J.M., Moon, G.J., Lee, P.H., Ahn, Y.H., Bang, O.Y., collaborators, S., 2010 A long-term follow-up study of intravenous autologous mesenchymal stem cel ransplantation in patients with ischemic stroke. Stem Cells 28, 1099-1106.

Lees, J.S., Sena, E.S., Egan, K.J., Antonic, A., Koblar, S.A., Howells, D.W., Macleod, M.R. 2012. Stem cell-based therapy for experimental stroke: a systematic review and meta-analysis. Int. J. Stroke: Off. J. Int. Stroke Soc. 7, 582-588.

Leon-Jimenez, C., Ruiz-Sandoval, J.L., Chiquete, E., Vega-Arroyo, M., Arauz, A. Murillo-Bonilla, L.M., Ochoa-Guzman, A., Carrillo-Loza, K., Ramos-Moreno, A. Barinagarrementeria, F., Cantu-Brito, C., Investigadores, P., 2014. Hospital arrival time and functional outcome after acute ischaemic stroke: results from the PREMIER study. Neurologia 29, 200-209.

Leten, C., Roobrouck, V.D., Struys, T., Burns, T.C., Dresselaers, T., Vande Velde, G. Santermans, J., Lo Nigro, A., Ibrahimi, A., Gijsbers, R., Eggermont, K., Lambrichts, I., Verfaillie, C.M., Himmelreich, U., 2014. Controlling and monitoring stem cel safety in vivo in an experimental rodent model. Stem Cells 32, 2833-2844.

Li, M.D., Burns, T.C., Morgan, A.A., Khatri, P., 2014. Integrated multi-cohor ranscriptional meta-analysis of neurodegenerative diseases. Acta Neuropathol. Commun. 2, 93

Li, W.Y., Choi, Y.J., Lee, P.H., Huh, K., Kang, Y.M., Kim, H.S., Ahn, Y.H., Lee, G., Bang, O. Y., 2008a. Mesenchymal stem cells for ischemic stroke: changes in effects after ex vivo culturing. Cell Transplant. 17, 1045-1059.

Li, Z., Suzuki, Y., Huang, M., Cao, F., Xie, X., Connolly, A.J., Yang, P.C., Wu, J.C., 2008b. Comparison of reporter gene and iron particle labeling for tracking fate of human embryonic stem cells and differentiated endothelial cells in living subjects. Stem Cells 26, 864-873.

Lo Nigro, A., Geraerts, M., Notelaers, T., Roobrouck, V.D., Muijtjens, M., Eggermont, K., Subramanian, K., Ulloa-Montoya, F, Park, Y, Owens, J., Burns, T.C., Low, W. Sharma, S., Sohni, A., Crabbe, A., Pauwelyn, K., Roelandt, P., Agirre, X., Prosper, F., O'Brien, T.D., Zwijsen, A., Hu, W.S., Binas, B., Verfaillie, C.M., 2012. MAPC culture conditions support the derivation of cells with nascent hypoblast features from bone marrow and blastocysts. J. Mol. Cell Biol. 4, 423-426.

Lukovic, D., Stojkovic, M., Moreno-Manzano, V., Bhattacharya, S.S., Erceg, S., 2014 Perspectives and future directions of human pluripotent stem cell-based therapies: lessons from Geron's clinical trial for spinal cord injury. Stem Cells Dev. 23, 1-4.

Magnusson, J.P., Goritz, C., Tatarishvili, J., Dias, D.O., Smith, E.M., Lindvall, O., Kokaia, Z., Frisen, J., 2014. A latent neurogenic program in astrocytes regulated by Notch signaling in the mouse. Science 346, 237-241.

Maguire, E.A., Gadian, D.G., Johnsrude, I.S., Good, C.D., Ashburner, J., Frackowiak, R. S., Frith, C.D., 2000. Navigation-related structural change in the hippocampi of taxi drivers. Proc. Natl. Acad. Sci. USA 97, 4398-4403.

Martinez, A.M., Goulart, C.O., Ramalho Bdos, S., Oliveira, J.T., Almeida, F.M., 2014 Neurotrauma and mesenchymal stem cells treatment: from experimenta studies to clinical trials. World J. Stem Cells 6, 179-194.

Martinez, H.R., Gonzalez-Garza, M.T., Moreno-Cuevas, J.E., Caro, E., GutierrezJimenez, E., Segura, J.J., 2009. Stem-cell transplantation into the frontal motor cortex in amyotrophic lateral sclerosis patients. Cytotherapy 11, 26-34.

Martino, G., Franklin, R.J., Baron Van Evercooren, A., Kerr, D.A., 2010. Stem cells in multiple sclerosis consensus, G. Stem cell transplantation in multiple sclerosis: current status and future prospects. Nat. Rev. Neurol. 6, 247-255.

Menn, B., Garcia-Verdugo, J.M., Yaschine, C., Gonzalez-Perez, O., Rowitch, D. Alvarez-Buylla, A., 2006. Origin of oligodendrocytes in the subventricular zone of the adult brain. J. Neurosci. Off. J. Soc. Neurosci. 26, 7907-7918.

Mouret, A., Lepousez, G., Gras, J., Gabellec, M.M., Lledo, P.M., 2009. Turnover of newborn olfactory bulb neurons optimizes olfaction. J. Neurosci.: Off. J. Soc. Neurosci. 29, 12302-12314.

Neha, Sodhi, Jaggi, R.K., Singh, N., A.S., 2014. Animal models of dementia and cognitive dysfunction. Life Sci. 109, 73-86.

'Collins, V.E., Macleod, M.R., Donnan, G.A., Horky, L.L., van der Worp, B.H., Howells, D.W., 2006. 1026 experimental treatments in acute stroke. Ann. Neurol. 59, 467-477.

Olanow, C.W., Goetz, C.G., Kordower, J.H., Stoessl, A.J., Sossi, V., Brin, M.F., Shannon, K.M., Nauert, G.M. Perl, D.P., Godbold, J., Freeman, T.B., 2003. A double-blin controlled trial of bilateral fetal nigral transplantation in Parkinson's disease. Ann. Neurol. 54, 403-414.

Oliveri, R.S., Bello, S., Biering-Sorensen, F., 2014. Mesenchymal stem cells improve locomotor recovery in traumatic spinal cord injury: systematic review with meta-analyses of rat models. Neurobiol. Dis. 62, 338-353.

Olson, S.D., Pollock, K., Kambal, A., Cary, W., Mitchell, G.M., Tempkin, J., Stewart, H. McGee, J., Bauer, G., Kim, H.S., Tempkin, T., Wheelock, V., Annett, G., Dunbar, G., 
Nolta, F., 2012. Genetically engineered mesenchymal stem cells as a proposed therapeutic for Huntington's disease. Mol. Neurobiol. 45, 87-98.

Panza, F., Logroscino, G., Imbimbo, B.P., Solfrizzi, V., 2014. Is there still any hope for amyloid-based immunotherapy for Alzheimer's disease? Curr. Opin. Psychiatry $27,128-137$.

Patzke, N., Spocter, M.A., Karlsson, K.A., Bertelsen, M.F., Haagensen, M., Chawana, R. Streicher, S., Kaswera, C., Gilissen, E., Alagaili, A.N., Mohammed, O.B., Reep, R.L., Bennett, N.C., Siegel, J.M., Ihunwo, A.O., Manger, P.R., 2013. In contrast to many other mammals, cetaceans have relatively small hippocampi that appear to lack adult neurogenesis. Brain Struct. Funct.

Peterson, S.E., Loring, J.F., 2014. Genomic instability in pluripotent stem cells: implications for clinical applications. J. Biol. Chem. 289, 4578-4584.

Polanco, J.C. Ho, M.S. Wang, B. Zhou, Q. Wolvetang. E., Mason, E., Wells, C.A. Kolle, G., Grimmond, S.M., Bertoncello, I., O'Brien, C., Laslett, A.L., 2013. Identification of unsafe human induced pluripotent stem cell lines using a robust surrogate assay for pluripotency. Stem Cells 31, 1498-1510.

Polgar, S., Morris, M.E., Reilly, S., Bilney, B., Sanberg, P.R., 2003. Reconstructive neurosurgery for Parkinson's disease: a systematic review and preliminary meta-analysis. Brain Res. Bull. 60, 1-24.

Prasad, K., Sharma, A., Garg, A., Mohanty, S., Bhatnagar, S., Johri, S., Singh, K.K., Nair, V., Sarkar, R.S., Gorthi, S.P., Hassan, K.M., Prabhakar, S., Marwaha, N., Khandelwal, N., Misra, U.K., Kalita, J., Nityanand, S., 2014. Intravenous autologous bone marrow mononuclear stem cell therapy for ischemic stroke: a multicentric randomized trial. Stroke J. Cereb. Circ.

Ramon y.Cajal, S., 1928. Degeneration and Regeneration of the Nervious System. Haffner Publishing Co, New York.

Reynolds, B.A., Tetzlaff, W. Weiss, S., 1992. A multipotent EGF-responsive striatal embryonic progenitor cell produces neurons and astrocytes. J. Neurosci.: Off. J. Soc. Neurosci. 12, 4565-4574.

Reynolds, B.A., Weiss, S., 1992. Generation of neurons and astrocytes from isolated cells of the adult mammalian central nervous system. Science 255, 1707-1710.

Richardson, R.M., Singh, A., Sun, D., Fillmore, H.L., Dietrich 3rd, D.W., Bullock, M.R., 2010. Stem cell biology in traumatic brain injury: effects of injury and strategies for repair. J. Neurosurg. 112, 1125-1138

Robinson, R., 2003. Fetal translpant study results prompt cal for halt to future trials. Neurol. Today 3, 9-10.

Roper, S.N., Steindler, D.A., 2013. Stem cells as a potential therapy for epilepsy. Exp. Neurol. 244, 59-66.

Sabelstrom, H., Stenudd, M., Reu, P., Dias, D.O., Elfineh, M., Zdunek, S., Damberg, P., Goritz, C., Frisen, J., 2013. Resident neural stem cells restrict tissue damage and neuronal loss after spinal cord injury in mice. Science 342, 637-640.

Salloway, S., Sperling, R., Fox, N.C., Blennow, K., Klunk, W., Raskind, M., Sabbagh, M., Honig, L.S., Porsteinsson, A.P., Ferris, S., Reichert, M., Ketter, N., Nejadnik, B., Guenzler, V., Miloslavsky, M., Wang, D., Lu, Y., Lull, J., Tudor, I.C., Liu, E. Grundman, M., Yuen, E., Black, R., Brashear, H.R., 2014. Bapineuzumab, clinical trial, I Two phase 3 trials of bapineuzumab in mild-to-moderate Alzheimer's disease. N. Engl. J. Med. 370, 322-333.

Sanai, N., Tramontin, A.D., Quinones-Hinojosa, A., Barbaro, N.M., Gupta, N., Kunwar, S., Lawton, M.T., McDermott, M.W., Parsa, A.T., Manuel-Garcia Verdugo, J., Berger, M.S., Alvarez-Buylla, A., 2004. Unique astrocyte ribbon in adult human brain contains neural stem cells but lacks chain migration. Nature 427 , $740-744$.

Savitz, S.I., Chopp, M., Deans, R., Carmichael, T., Phinney, D., Wechsler, L., 2011. Participants, stem cell therapy as an emerging paradigm for stroke (STEPS) II. Stroke J. Cereb. Circ. 42, 825-829.

Savitz, S.I., Cramer, S.C., Wechsler, L., 2014. Consortium, stem cells as an emerging paradigm in stroke 3: enhancing the development of clinical trials. Stroke J. Cereb. Circ. 45, 634-639.

Scott, S., Kranz, J.E., Cole, J., Lincecum, J.M., Thompson, K., Kelly, N., Bostrom, A., Theodoss, J., Al-Nakhala, B.M., Vieira, F.G., Ramasubbu, J., Heywood, J.A., 2008. Design, power, and interpretation of studies in the standard murine model of ALS. Amyotroph. Lateral Scler.: Off. Publ. World Fed. Neurol. Res. Group Motor Neuron Dis. 9, 4-15.

Selden, N.R., Al-Uzri, A., Huhn, S.L., Koch, T.K., Sikora, D.M., Nguyen-Driver, M.D., Guillaume, D.J., Koh, J.L., Gultekin, S.H., Anderson, J.C., Vogel, H., Sutcliffe, T.L., Jacobs, Y., Steiner, R.D., 2013. Central nervous system stem cell transplantation for children with neuronal ceroid lipofuscinosis. J. Neurosurg. Pediatr. 11, 643-652.

Sena, E.S., van der Worp, H.B, Bath, P.M., Howells, D.W. Macleod, M.R, 2010. Publication bias in reports of animal stroke studies leads to major overstatement of efficacy. PLoS Biol. 8, e1000344.

Serafini, M., Dylla, S.J., Oki, M., Heremans, Y., Tolar, J., Jiang, Y., Buckley, S.M. Pelacho, B., Burns, T.C., Frommer, S., Rossi, D.J., Bryder, D., Panoskaltsis-Mortari, A., O'Shaughnessy, M.J., Nelson-Holte, M., Fine, G.C., Weissman, I.L., Blazar, B.R.,
Verfaillie, C.M., 2007. Hematopoietic reconstitution by multipotent adult progenitor cells: precursors to long-term hematopoietic stem cells. J. Exp. Med. 204, 129-139.

Song, L., Huang, Q., Chen, K., Liu, L., Lin, C., Dai, T., Yu, C., Wu, Z., Li, J., 2010. miR-218 inhibits the invasive ability of glioma cells by direct downregulation of IKKbeta. Biochem. Biophys. Res. Commun. 402, 135-140.

Spalding, K.L., Bergmann, O., Alkass, K., Bernard, S., Salehpour, M., Huttner, H.B., Bostrom, E., Westerlund, I., Vial, C., Buchholz, B.A., Possnert, G., Mash, D.C., Druid, H., Frisen, J., 2013. Dynamics of hippocampal neurogenesis in adult humans. Cell 153, 1219-1227.

Stem Cell Therapies as an emerging paradigm in stroke, Participants, 2009. Stem Cell Therapies as an Emerging Paradigm in Stroke (STEPS): bridging basic and clinical science for cellular and neurogenic factor therapy in treating stroke. Stroke J. Cereb. Circ. 40, 510-515.

Stinear, C.M., Byblow, W.D., 2014. Predicting and accelerating motor recovery after stroke. Curr. Opin. Neurol. 27, 624-630.

Sundberg, M., Bogetofte, H., Lawson, T., Jansson, J., Smith, G., Astradsson, A., Moore, M., Osborn, T., Cooper, O., Spealman, R., Hallett, P., Isacson, O., 2013. Improved cell therapy protocols for Parkinson's disease based on differentiation efficiency and safety of hESC-, hiPSC-, and non-human primate iPSC-derived dopaminergic neurons. Stem Cells 31, 1548-1562.

Teasell, R., Mehta, S., Pereira, S., McIntyre, A., Janzen, S., Allen, L., Lobo, L., Viana, R., 2012. Time to rethink long-term rehabilitation management of stroke patients. Top. Stroke Rehabil. 19, 457-462.

Teng, Y.D., Benn, S.C., Kalkanis, S.N., Shefner, J.M., Onario, R.C., Cheng, B., Lachyankar, M.B., Marconi, M., Li, J., Yu, D., Han, I., Maragakis, N.J., Llado, J., Erkmen, K., Redmond Jr., D.E., Sidman, R.L., Przedborski, S., Rothstein, J.D., Brown Jr., R.H., Snyder, E.Y., 2012. Multimodal actions of neural stem cells in a mouse model of ALS: a meta-analysis. Sci. Transl. Med.4 165ra164.

Thomsen, G.M., Gowing, G., Svendsen, S., Svendsen, C.N., 2014. The past, present and future of stem cell clinical trials for ALS. Exp. Neurol. 262, 127-137.

Tolar, J., Nauta, A.J., Osborn, M.J., Panoskaltsis Mortari, A., McElmurry, R.T., Bell, S. Xia, L., Zhou, N., Riddle, M., Schroeder, T.M., Westendorf, J.J., McIvor, R.S., Hogendoorn, P.C., Szuhai, K., Oseth, L., Hirsch, B., Yant, S.R., Kay, M.A., Peister, A., Prockop, D.J., Fibbe, W.E., Blazar, B.R., 2007. Sarcoma derived from cultured mesenchymal stem cells. Stem Cells 25, 371-379.

van der Worp, H.B., de Haan, P., Morrema, E., Kalkman, C.J., 2005. Methodological quality of animal studies on neuroprotection in focal cerebral ischaemia. J. Neurol. 252, 1108-1114.

van der Worp, H.B., Howells, D.W., Sena, E.S., Porritt, M.J., Rewell, S., O'Collins, V., Macleod, M.R., 2010. Can animal models of disease reliably inform human studies? PLoS Med. 7, e1000245.

Villeda, S.A., Plambeck, K.E., Middeldorp, J., Castellano, J.M., Mosher, K.I., Luo, J., Smith, L.K., Bieri, G., Lin, K., Berdnik, D., Wabl, R., Udeochu, J., Wheatley, E.G., Zou, B., Simmons, D.A., Xie, X.S., Longo, F.M., Wyss-Coray, T., 2014. Young blood reverses age-related impairments in cognitive function and synaptic plasticity in mice. Nature Med. 20, 659-663.

Vu, Q., Xie, K., Eckert, M., Zhao, W., Cramer, S.C., 2014. Meta-analysis of preclinical studies of mesenchymal stromal cells for ischemic stroke. Neurology 82, 1277-1286.

Wahlberg, L.U., Lind, G., Almqvist, P.M., Kusk, P., Tornoe, J., Juliusson, B., Soderman, M., Sellden, E., Seiger, A., Eriksdotter-Jonhagen, M., Linderoth, B. 2012. Targeted delivery of nerve growth factor via encapsulated cell biodelivery in Alzheimer disease: a technology platform for restorative neurosurgery. J. Neurosurg. 117, 340-347.

Wurmser, A.E., Gage, F.H., 2002. Stem cells: cell fusion causes confusion. Nature 416, 485-487.

Xiong, Y., Mahmood, A., Chopp, M., 2013. Animal models of traumatic brain injury. Nat. Rev. Neurosci. 14, 128-142.

Xu, L., Yan, J., Chen, D., Welsh, A.M., Hazel, T., Johe, K., Hatfield, G., Koliatsos, V.E., 2006. Human neural stem cell grafts ameliorate motor neuron disease in SOD-1 transgenic rats. Transplantation 82, 865-875.

Yan, J., Xu, L., Welsh, A.M., Hatfield, G., Hazel, T., Johe, K., Koliatsos, V.E., 2007. Extensive neuronal differentiation of human neural stem cell grafts in adult rat spinal cord. PLoS Med. 4, e39.

Yeung, M.S., Zdunek, S., Bergmann, O., Bernard, S., Salehpour, M., Alkass, K., Perl, S., Tisdale, J., Possnert, G., Brundin, L., Druid, H., Frisen, J., 2014. Dynamics of oligodendrocyte generation and myelination in the human brain. Cell 159, 766-774.

Yu, S.P., Wei, Z., Wei, L., 2013. Preconditioning strategy in stem cell transplantation therapy. Transl. Stroke Res. 4, 76-88.

Zhu, J., Zhou, L., XingWu, F., 2006. Tracking neural stem cells in patients with brain trauma. N. Engl. J. Med. 355, 2376-2378. 